\title{
Investigation of Factors Affecting Students' Science Achievement According to Student Science Teachers
}

\section{Erdal Tatar}

Assoc. Prof. Dr., Mustafa Kemal University, Turkey, erdaltatares@gmail.com

Cengiz Tüysüz

Assoc. Prof. Dr., Uşak University, Turkey, ctuysuz@gmail.com

Cemal Tosun

Assoc. Prof. Dr., Bartın University, Turkey, cemaltosun22@gmail.com

\section{Nail İlhan}

Asst. Prof. Dr., Kilis 7 Aralık University, Turkey, naililhan@gmail.com

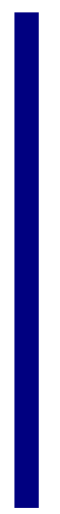
In this study, it was aimed to investigate the factors affecting students' science achievement according to student science teachers. The survey model which is one of the quantitative research methods was used. The sample was consisted of total 606 student science teachers from four state universities in Turkey. The data were obtained by using the Questionnaire of Factors Affecting Students' Science Achievement (QFASSA). The data were analyzed by using the descriptive analyzing technique. The factors affecting students' science achievement were analyzed under five dimensions. The result of the study shows that the most important factors affecting student science achievement according to student science teachers are the items in the dimensions of teacher and curriculum. The results also indicates that the most important predictor of science achievement is "teaching the topics in a way that may arouse the students' curiosity" in the teacher dimension of QFASSA.

Key Words: predictors of science achievement, academic achievement, science education, teacher, affecting students

\section{INTRODUCTION}

Turkey has taken place at the end of the list in the Program for International Student Assessment (PISA) in terms of science achievement since 2003. PISA has assessed 15year-old students from the majority of the Organization for Economic Cooperation and Development (OECD) countries. In the latest PISA held in 2012, Turkey was ranked 43 among 65 countries in the field of science achievement (PISA, 2012). Turkey's position is no different in Trends in International Mathematics and Science Study (TIMSS). According to the TIMSS 2011 data, Turkey was ranked 36 among 50 countries in the fourth grade level and was ranked 21 among 42 countries in the eighth grade level. So it 
was below the average of the countries in the field of science achievement (TIMSS, 2011a; 2011b).

Students' science achievement is affected by many factors. However, to determine what factor or factors actually caused this negative situation is important for the future of science education. In this case, it may be able to yield enough from the studies such as educational reform, policies, and changes in curriculum.

Until today, the lack of universal model developed to determine the predictors of science achievement might be due to that the countries have different cultural and educational institutions (Dryden, 1987; Wang \& Staver, 1996). Each country may have its own specific unresolved problems related to science education. Comprehensive studies on the predictors of science achievement can help the people in authority to find solutions to the problems of science education. Such studies can give them an idea of what factors and how much it would need an intervention for solution.

In the educational research literature, there are available many studies which have been conducted on the factors affecting academic achievement in science such as: students' self-perception of competence (Shen \& Pedulla, 2000), student background characteristics (Areepattamannil \& Kaur, 2013), classroom characteristics (Yore, Shymansky \& Anderson 2002), interest in science, reactive curiosity and scholastic aptitude (Harty, Beall, \& Scharmann 1985), instructional activities (House, 2000), selfconcept (Wang, Oliver \& Staver 2008). In studies conducted in Turkey, researchers have found that several factors such as attitudes toward science, (Akpınar et al., 2009), affective factors (Ozel, Caglak, \& Erdogan, 2013), science literacy level of parents (Şahin, Sanalan, Bektaş, \& Kaygısız, 2010), kindergarten science experiences (Kumtepe, Kaya, \& Kumtepe, 2009) gender, school starting age and parent's education level (Gursakal, 2012), engagement and readiness to learn (Yetişir, 2014), and socioeconomic level (Tomul \& Celik 2009) affect the science achievement.

However, it has seen that these studies carried out on only a few factors as independent variable. Also the modelling studies that can explain the predictors of science achievement in a holistic manner are very limited. Tosun et al., (2015) aimed to identify the factors that affect the academic achievement based on the perceptions of students in levels of middle school, high school and university. According to the results of the study, most of the students stated that the most important factors for the achievement in science classes are first student-sourced, and secondly teacher-sourced. Also the common factors for all three levels were found as working subject repeat, doing experiments, and teaching methods, and techniques used by the teacher. Ceylan and Berberoğlu (2007) investigated the factors affecting students' science achievement in the TIMMS 1999. They found that there were negative relationships between students' perception of failure in science, student-centered activities and science achievement level and there was a positive relationship between teacher-centered activities and science achievement level. Anıl (2011) aimed to model a work between students' science achievement scores in PISA 2006 and their responses to the questionnaire. She found that the most significant factors determining science achievement were the time devoted to science, the learning environment, parents' education level and attitudes toward science, respectively. 
This study aimed to investigate the factors affecting students' science achievement according to student science teachers in a holistic manner. Such a study is considered shed light for the educational policy-makers and managers to find solutions to the problems and for educational researchers about their future studies.

\section{METHOD}

In this study, the survey model which is one of the quantitative research methods was used. The survey model aims to describe a situation which has happened in the past or present as reality (Karasar, 2006).

\section{Study Samples}

This study was carried out on students from four state universities in the fall semester of 2015-2016 academic year in Turkey. The sample consisted of 606 student science teachers studying at science education departments of Mustafa Kemal University, Uşak University, Bartın University, and Kilis 7 Aralık University. They were selected using the convenience sampling technique, one of non-random sampling methods. Researchers may use convenience sampling technique when selection of the sample is difficult by using random or systematic nonrandom sampling techniques. The sample selected by using the convenience sampling consists of individuals who are available for study easily (Fraenkel \& Wallen, 2006; p.99). Some demographics data about the sample are given in Table 1.

Table 1: Demographics data about the sample

\begin{tabular}{|c|c|c|c|c|c|c|c|}
\hline University & Gender & Grade & $N$ & University & Gender & Grade & $N$ \\
\hline \multirow{8}{*}{$\begin{array}{l}\text { Mustafa } \\
\text { Kemal }\end{array}$} & \multirow{5}{*}{ Female } & 1 & 42 & \multirow{8}{*}{ Bartın } & \multirow{4}{*}{ Female } & 1 & 35 \\
\hline & & 2 & 51 & & & 2 & 21 \\
\hline & & 3 & 44 & & & 3 & 26 \\
\hline & & 4 & 23 & & & 4 & 26 \\
\hline & & 1 & 12 & & \multirow{4}{*}{ Male } & 1 & 9 \\
\hline & \multirow{3}{*}{ Male } & 2 & 9 & & & 2 & 2 \\
\hline & & 3 & 10 & & & 3 & 7 \\
\hline & & 4 & 8 & & & 4 & 8 \\
\hline \multirow{8}{*}{ Uşak } & \multirow{4}{*}{ Female } & 1 & 27 & \multirow{8}{*}{ Kilis 7 Aralık } & \multirow{4}{*}{ Female } & 1 & 32 \\
\hline & & 2 & 28 & & & 2 & 33 \\
\hline & & 3 & 14 & & & 3 & 32 \\
\hline & & 4 & 15 & & & 4 & 35 \\
\hline & \multirow{4}{*}{ Male } & 1 & 7 & & \multirow{4}{*}{ Male } & 1 & 2 \\
\hline & & 2 & 9 & & & 2 & 11 \\
\hline & & 3 & 6 & & & 3 & 8 \\
\hline & & 4 & 7 & & & 4 & 7 \\
\hline
\end{tabular}

\section{Data collection}

To collect the data in this study, "Questionnaire of Factors Affecting Students' Science Achievement" (QFASSA) developed by Tatar el al. (2015) was used after being modified. The questionnaire consists of five dimensions named as student, teacher, material/activity, learning environment, and curriculum and 29 items in its original 
form. For this study, the questionnaire was modified by adding a new dimension consisting of five items. These items are the names of the dimensions in the original form. Finally, the questionnaire consists of six dimensions and 34 items (Appendix-1). Each item of the questionnaire are possible factors with the potential to affect students' science achievement. It was asked to determine a percentage compared to the impact on science achievement from the student science teachers. It also was said them the sum of the impact values must not exceed 100 percent for each dimension.

\section{Data Analysis}

The data of the study was analyzed by using the descriptive analyzing technique. The impact value of each factor was calculated both in its dimensions and in all factors. So, the role of each factor was determined for science achievement. The averages of the percentage determined by the student science teachers were calculated and they were presented in tables.

\section{FINDINGS}

The impact values were determined as percentage using data obtained from student science teachers. The average value of the percentage determined by the student science teachers about each factor demonstrates the impact value as percentage for the factor. The impact values of the dimensions on science achievement are shown in Table 2.

Table 2: The impact values of the dimensions

\begin{tabular}{lc}
\hline Dimensions & Impact value \% \\
\hline Teacher & 29,66 \\
\hline Student & 26,05 \\
\hline Material/Activity & 16,02 \\
\hline Curriculum & 14,98 \\
\hline Learning environment & 13,29 \\
\hline
\end{tabular}

According to the findings, it was determined that the student science teachers thought that students' science achievement was affected by teacher 29,66 percent, by student 26,05 percent, by material/activity 16,02 percent, by curriculum 14,98 percent, and by learning environment 13,29 percent.

The percentage distribution to the factor of the impact value of the teacher dimension $(29,66 \%)$ is given in Table 3.

Table 3: The impact values of the factors in the teacher dimension

\begin{tabular}{lc}
\hline Factors about teacher & Impact value \% \\
\hline Teaching the topics in a way that may arouse the curiosity of students. & 8,74 \\
\hline Consideration of individual differences among students. & 5,36 \\
\hline Self-motivating for lecturing. & 5,21 \\
\hline To provide control of the classroom. & 5,18 \\
\hline Self-renewal along with the development of science simultaneously. & 5,17 \\
\hline
\end{tabular}


The data analysis shows that students' science achievement was affected by teaching the topics in a way that may arouse the curiosity of students 8,74 percent, consideration of individual differences among students 5,36 percent, self-motivating of teacher for lecturing 5,21 percent, providing control of the classroom by teacher 5,18 percent, and continuous self-renewal of teacher along with the development of science simultaneously 5,17 percent.

The percentage distribution to the factors of the impact value of the student dimension $(26,05 \%)$ is shown in Table 4.

Table 4: The impact values of the factors in the student dimension

\begin{tabular}{lc}
\hline Factors about students & Impact value \% \\
\hline Doing subject again after the course & 4,42 \\
\hline To study regularly & 4,17 \\
\hline Taking notes regularly in course & 3,31 \\
\hline Solving the tests / questions related topics & 3,22 \\
\hline Active participation to science learning & 3,22 \\
\hline Asking the questions about issues not understood in course & 2,81 \\
\hline Coming prepared for the science course & 2,64 \\
\hline Doing science homework & 2,26 \\
\hline
\end{tabular}

The analysis also indicate that students' science achievement was affected by doing subject again after the course 4,42 percent, studying regularly 4,17 percent, taking notes regularly in course 3,31 percent, solving the tests / questions related issues 3,22 percent, active participation to science learning 3,22 percent, asking the questions about issues not understood in course 2,81 percent, coming prepared for the science course 2,64 percent, and doing science homework 2,26 percent.

The percentage distribution to the factors of the impact value of the material/activity dimension $(16,02 \%)$ on students' science achievement is presented in Table 5.

Table 5: The impact values of the factors in the material/activity dimension

\begin{tabular}{lc}
\hline Factors about material/activity & Impact value \% \\
\hline The frequency of making experimentation & 2,98 \\
\hline Using laboratory & 2,53 \\
\hline Doing hands-on activities in the courses & 2,17 \\
\hline The sufficiency of training tools & 1,83 \\
\hline Using different teaching materials other than textbooks & 1,78 \\
\hline Making the project on science topics & 1,68 \\
\hline Using technology in the science course & 1,63 \\
\hline Processing course based internet/computer & 1,42 \\
\hline
\end{tabular}

In the study, it also was determined that the student science teachers thought that students' science achievement was affected by the frequency of making experimentation 2,98 percent, using laboratory 2,53 percent, doing hands-on activities in the courses 2,17 percent, the sufficiency of training tools 1,83 percent, using different teaching materials other than textbooks 1,78 percent, making the project on science topics 1,68 percent, using technology in the science course 1,63 percent, and processing course based internet/computer 1,42 percent. 
The percentage distribution to the factor of the impact value of the curriculum dimension $(14,98 \%)$ on students' science achievement is given in Table 6.

Table 6: The impact values of the factors in the curriculum dimension

\begin{tabular}{lc}
\hline Factors about curriculum & Impact value \% \\
\hline The intensity of the science curriculum & 5,40 \\
\hline Having mainly quantitative content of the science topics & 5,18 \\
\hline Having abstract content of the science topics & 4,40 \\
\hline
\end{tabular}

The data analysis shows that students' science achievement was affected by the intensity of the science curriculum 5,40 percent, having mainly quantitative content of the science topics 5,18 percent, having abstract content of the science topics 4,40 percent.

The percentage distribution to the factors of the impact value of the learning environment dimension $(13,29 \%)$ is shown in Table 7.

Table 7: The impact values of the factors in the learning environment dimension

\begin{tabular}{lc}
\hline Factors about learning environment & Impact value \% \\
\hline The friendship environment in science classroom & 3,52 \\
\hline Existence of a person interested in science in the family & 2,71 \\
\hline Family support for science studies & 2,63 \\
\hline The physical condition of the classroom & 2,36 \\
\hline The seating arrangement in the classroom & 2,07
\end{tabular}

As shown in Table 7, the student science teachers thought that students' science achievement was affected by the friendship environment in science classroom 3,52 percent, existence of a person interested in science in the family 2,71 percent, family support for science studies 2,63 percent, the physical condition of the classroom 2,36 percent, and the seating arrangement in the classroom 2,07 percent.

The impact values of all factors that affected students' science achievement are shown in Table 8 as percentage. The factors are presented with their dimensions and listed according to the size of the impact value.

Table 8: The impact values of the all factors on students' science achievement

\begin{tabular}{lllc}
\hline & Dimensions & Factors & Impact value \% \\
\hline 1 & Teacher & $\begin{array}{l}\text { Teaching the topics in a way that may arouse the curiosity of } \\
\text { students. }\end{array}$ & 8,74 \\
\hline 2 & Curriculum & The intensity of the science curriculum & 5,40 \\
\hline 3 & Teacher & Consideration of individual differences among students. & 5,36 \\
\hline 4 & Teacher & Self-motivating for lecturing. & 5,21 \\
\hline 5 & Teacher & To provide control of the classroom. & 5,18 \\
\hline 6 & Curriculum & Having mainly quantitative content of the science topics & 5,18
\end{tabular}


Table 8: The impact values of the all factors on students' science achievement(continue)

\begin{tabular}{|c|c|c|c|}
\hline & Dimensions & Factors & $\begin{array}{l}\text { Impact } \\
\text { value } \%\end{array}$ \\
\hline 7 & Teacher & $\begin{array}{l}\text { Self-renewal along with the development of science } \\
\text { simultaneously. }\end{array}$ & 5,17 \\
\hline 8 & Student & Doing subject again after the course & 4,42 \\
\hline 9 & Curriculum & Having abstract content of the science topics & 4,40 \\
\hline 10 & Student & To study regularly & 4,17 \\
\hline 11 & Learning environment & The friendship environment in science classroom & 3,52 \\
\hline 12 & Student & Taking notes regularly in course & 3,31 \\
\hline 13 & Student & Solving the tests / questions related topics & 3,22 \\
\hline 14 & Student & Active participation to science learning & 3,22 \\
\hline 15 & Material/Activity & The frequency of making experimentation & 2,98 \\
\hline 16 & Student & $\begin{array}{l}\text { Asking the questions about issues not understood in } \\
\text { course }\end{array}$ & 2,81 \\
\hline 17 & Learning environment & Existence of a person interested in science in the family & 2,71 \\
\hline 18 & Student & Coming prepared for the science course & 2,64 \\
\hline 19 & Learning environment & Family support for science studies & 2,63 \\
\hline 20 & Material/Activity & Using laboratory & 2,53 \\
\hline 21 & Learning environment & The physical condition of the classroom & 2,36 \\
\hline 22 & Student & Doing science homework & 2,26 \\
\hline 23 & Material/Activity & Doing hands-on activities in the courses & 2,17 \\
\hline 24 & Learning environment & The seating arrangement in the classroom & 2,07 \\
\hline 25 & Material/Activity & The sufficiency of training tools & 1,83 \\
\hline 26 & Material/Activity & Using different teaching materials other than textbooks & 1,78 \\
\hline 27 & Material/Activity & Making the project on science topics & 1,68 \\
\hline 28 & Material/Activity & Using technology in the science course & 1,63 \\
\hline 29 & Material/Activity & Processing course based internet/computer & 1,42 \\
\hline
\end{tabular}

As shown in Table 8, the most important factors affecting students' science achievement according to student science teachers are the items in the dimensions of teacher and curriculum. It is stated that Teaching the topics in a way that may arouse the curiosity of students in the teacher dimension is the most important factor in all the 29 factors. Also 
it was evaluated that all the other factors covered by the teacher dimension as the predictors of science achievement above 5 percent level.

The results indicate that the factors of The intensity of the science curriculum, Having mainly quantitative content of the science topics, and Having abstract content of the science topics in the curriculum dimension are among the most important first 10 predictors of science achievement. Also the factors of Doing subject again after the course and To study regularly in the student dimension are among the most important first 10 predictors of science achievement.

Also as shown in Table 8, the least important factors affecting students' science achievement according to student science teachers are the items of The sufficiency of training tools, Using different teaching materials other than textbooks, Making the project on science topics, Using technology in the science course, and Processing course based internet/computer in the material/activity dimension. It was evaluated that these factors as the predictors of science achievement below 2 percent level.

\section{DISCUSSION}

In this study, it was aimed to investigate the factors affecting students' science achievement according to student science teachers. The data showed that the most important predictor of science achievement is teaching the topics in a way that may arouse the curiosity of students.

To arouse the sense of curiosity towards science lesson for students is the teacher's duty. In the document of primary schools curriculum in science also emphasize the sense of curiosity (President of the Board of Education, 2013). In addition, the US National Science Education Standards (National Research Council, 1995) stated that one of the tasks of science teachers is to arouse a sense of curiosity in students. Also in the educational literature, the related studies reported a positive correlation between students' science academic achievement and their curiosity level towards science (Hart \& Beall, 1984; Harty et al., 1985; Serin, 2010).

Anıl (2011) argues to be effective of teacher's quality in teaching as well as to be effective of the student's individual abilities in learning. Similar results were revealed in this study. The factors of Consideration of individual differences among students, Selfmotivating for lecturing, To provide control of the classroom, and To provide control of the classroom covered by the teacher dimension were considered as the predictors of science achievement above 5 percent level. Also Ceylan and Berberoğlu (2007) recommended teachers to follow developmental level by addressing students' learning individually about predictors of science achievement.

The factors such as The intensity of the science curriculum, and Having mainly quantitative content of the science topics in the curriculum dimension have been found to be among the most important predictors of science achievement. Ceylan and Berberoğlu (2007) referred that students cannot do spare time to activities out of school because of the intensity of the science curriculum in Turkey. In many countries as in 
Turkey, the curriculums are being criticized and arrangements have been made since the content of the curriculum is too wide (Gilbert, 2006).

There were no studies in the literature related that the quantitative content of the science curriculum is an important predictor of science achievement. However Tatar (2015) stated that solving chemical problems has an important role to be successful students in the chemistry courses. It was reported that math has a significant impact on chemistry education (Denny, 1971) and on physics education (Monk, 1994). It was also referred that the science cannot be independent from mathematics (Eisner, 1991) and mathematics and science should be carried out together (Tzanakis, 1999).

Anil (2011) conducted to determine the factors affecting the science scores of PISA 2016 of Turkey. Anil mentioned that learning environment (having a room at home, a desk, a computer and internet connection) is the most important second factor affecting students' science achievement in the study. On the other hand almost all the studies related to computer using in science education mentioned that it positively affects science achievement (Arıkan, Aydoğdu, Doğru \& Uşak, 2006; Yiğit \& Akdeniz 2003; Çekbaş, Yakar, Yıldırım \& Savran, 2003; Güven \& Sülün, 2012; Pektaş, Solak \& Türkmen, 2006; Katırcıŏlu \& Kazanc1, 2003; Yenice, Sümer, Oktaylar \& Erbil, 2003) In contrast to these results, computer and internet connection took place under the material dimension in this study and was evaluated as the predictor of science achievement below 2 percent level. So it is thought that this may be an important factor, but it is less important relatively among other factors for science achievement.

\section{RECOMMENDATIONS}

Based on this study's findings may be made the following recommendations:

1. It may benefit from the learning methods (e.g. context, problem, project based learning) increasing the curiosity level of students.

2. Students learning should be considered on an individual basis and levels of their cognitive development should be monitored accordingly.

3. It should be supported the learning of students with insufficient in solving numerical science problems by providing additional courses.

4. The intensity of the science curriculum should be reconsidered by the educational policies.

\section{REFERENCES}

Akpınar, E. Yıldız, N. Tatar, Ö. Ergin, (2009). Students' attitudes toward science and technology: an investigation of gender, grade level, and academic achievement. Procedia Social and Behavioral Sciences, 1 (2009), pp. 2804-2808.

An1l, D. (2011). Investigation of factors influencing Turkey's Pisa 2006 science achievement with structural equation modelling. Educational Sciences: Theory \& Practice, 11(3), 1253-1266. 
Areepattamannil, S., \& Kaur, B. (2013). Factors predicting science achievement of immigrant and non-immigrant students: A multilevel analysis. International Journal of Science and Mathematics Education, 11(5), 1183 -1207.

Arıkan, F., Aydoğdu, M., Doğru, M., Uşak, M. 2006. bilgisayar destekli biyoloji öğretiminin öğrenci başarisina etkisi, Milli Eğitim Dergisi, 171.

Ceylan, E., \& Berberoğlu, G. (2007). Factors related with students' science achievement: A modeling study. Education and Science, 32 (144), 36-48.

Çekbaş, Y., Yakar, H., Yıldırım, B. ve Savran, A. (2003). Bilgisayar destekli eğitimin öğrenciler üzerine etkisi, The Turkish Online Journal of Educational Technology (TOJET), 2(4), 11.

Denny, R.T. (1971). The mathematics skill test (MAST) for chemistry. Journal of Chemical Eduation, 48(12), 845-846.

Dryden, M. (1987). Modeling classroom environment: An analysis of achievement at the ninth grade level. Doctoral dissertation, State University of New York, Buffalo.

Eisner, M.P. (1991). In my opinion, physics educators and mathematics educators should work together. The Physics Teacher, 29(11), 478-480.

Fraenkel, J. R., \& Wallen, N. E. (2006). How to design and evaluate research in education ( $6^{\text {th }}$ ed.). Boston: McGraw Hill Higher Education.

Gilbert, J.K. (2006). On the nature of context in chemical education. International Journal of Science Education, 28(9), 957-976.

Güven, G. ve Sülün, Y. (2012) Bilgisayar destekli öğretimin 8.sınıf fen ve teknoloji dersindeki akademik başarıya ve öğrencilerin derse karşı tutumlarına etkisi, Türk Fen Ĕ̈itimi Dergisi, 9(1), 68-79

Harty, H., \& Beall, D. (1984). Toward the development of a children's science curiosity measure. Journal of Research in Science Teaching, 21(4), 425-436.

Harty, H., \& Beall, D., \& Scharmann, L. (1985). Relationships between elementary school students' science achievement and their attitudes toward science, interest in science, reactive curiosity, and scholastic aptitude. School Science and Mathematics, 85(6), 472-479.

House, J. D. (2000). Relationships between instructional activities and science achievement of adolescent students in Hong Kong: Findings from the Third International Mathematics and Science Study (TIMSS). International Journal of Instructional Media, 27, 275-288.

Gürsakal, S. (2012). PISA 2009 öğrenci başarı düzeylerini etkileyen faktörlerin değerlendirilmesi. Suleyman Demirel University the Journal of Faculty of Economics and Administrative Sciences. 17(1), 441-452. 
Karasar, N. (2006). Bilimsel araştirma yöntemi (16. Bask1). Ankara: Nobel Yayın Dağıtım.

Katırcıŏlu, H. ve Kazancı, M. (2003). Genel biyoloji derslerinde bilgisayar kullanımının öğrenci başarısı üzerine etkisi. Hacettepe Üniversitesi Eğitim Fakültesi Dergisi, 25, 127-134.

Kumtepe, E. G., Kaya, S., \& Kumtepe, A. T. (2009). The effects of kindergarten experiences on children's elementary science achievement. Elementary Education Online, 8(3), 978-987.

McKnight, C. C., \& Schmidt, W. H. (1998). Facing facts in U.S. science and mathematics education: Where we stand, where we want to go. Journal of Science Education and Technology, 7, 57-76.

Monk, M. (1994). Mathematics in physics education: A case of more hoste less speed. Physics Education, 29(4), 209-211.

National Research Council (1995). National science education standards. Washington, DC: National Academy Press.

Ozel, M., Caglak, S., \& Erdogan, M. (2013). Are affective factors a good predictor of science achievement? Examining the role of affective factors based on PISA 2006. Learning and Individual Differences, 24, 73-82.

Ozerbas, M.A. (2007). Yapilandirmaci öğrenme ortaminin öğrencilerin akademik başarilarina ve kaliciliğina etkisi, - Türk Ĕgitim Bilimleri Dergisi, 5(4), 609-635

Pektaş, M., Solak, K., \& Türkmen, L. (2006). Bilgisayar destekli öğretimin fen bilgisi öğretmen adaylarinin sindirim sistemi ve boşaltim sistemi konularini öğrenmeleri üzerine etkisi. Kastamonu Ĕgitim Dergisi, 14(2), 465-472.

PISA (2012). National report. PISA Türkiye. Milli Eğitim Bakanlığı. Ankara.

Serin, G. (2010). Investigation of $7^{\text {th }}$ grade elementary students' science curiosity. Mustafa Kemal Üniversitesi Sosyal Bilimler Ensitüsü Dergisi, 7(13), 237-252.

Shen C., \& Pedulla J.J. (2000). The relationship between students' achievement and their self- perception of competence and rigour of mathematics and science: A crossnational analysis. Assessment in Education, 7(2), 237-253.

Şahin, R. , Sanalan, V. A. , Bektaş, Ö. ve Kaygısız, Y. (2010). Ebeveynlerin fen okuryazarlik düzeylerinin ilköğretim 7.sinif öğrencilerinin fen ve teknoloji dersi başarilarina etkisi. EÜFBED - Fen Bilimleri Enstitüsü Dergisi,3(1), 125-143.

Talim Terbiye Kurulu Başkanlığı, (2013). Ilköğretim kurumları (ilkokullar ve ortaokullar) fen bilimleri dersi (3, 4, 5, 6, 7 ve 8. sinıflar) ögretim programı. Ankara: MEB.

Tatar, E. (2015). A chemical problem solving technique: Stoichiometric mapping. Bartın University, Journal of Faculty of Education, 4(2), 576-585. 
Tatar, E., Tosun, C., Tüysüz, C., İlhan, N., \& Karakuyu, Y. (2015). Developing a scale to determining factors affecting students' achievement in science. Uşak Üniversitesi Sosyal Bilimler Dergisi, 8(4), 319-340.

TIMSS (2011a). National math and science report: Grade 4. Milli Eğitim Bakanlığı. Ankara. Accessed date 03.Jan.2016, from http://timss.meb.gov.tr/.

TIMSS (2011b). National math and science report: Grade 4. Milli Eğitim Bakanlı̆ğ. Ankara. Accessed date 03.Jan.2016, from http://timss.meb.gov.tr/.

Tomul, E., \& Celik, K. (2009). The relationship between the students' academics achievement and their socioeconomic level: cross regional comparison. In $\mathrm{H}$. Uzunboylu, \& N. Cavus (Eds.),World Conference on Educational Sciences-New trends and issues in educational sciences, Vol. 1.(pp.1199-1204)Amsterdam: Elsevier Science Bv.

Tosun, C., İlhan, N., Tatar, E., Tüysüz, C. \& Karakuyu, Y. (2015). Middle, high school and university students' predictors of science achievement. Mehmet Akif Ersoy University Journal of Education Faculty, 35, 29-45.

Tzanakis, C. (1999). Unfolding interrelations between mathematics and physics in a presentation motivated by history: Two examples. International Journal of Mathematical Education in Science and Technology, 30(1), 103-118.

Wang, J. J., Oliver, J. S., \& Staver, J. R. (2008). Self-concept and science achievement: Investigating a reciprocal relation model across tine gender classification in a crosscultural context. Journal of Research in Science Teaching, 45(6), 711-725

Wang, J. J. and Staver, J. R. (1996). An empirical approach toward the prediction of students' science achievement in the United States and Hubei, China. Journal of Research in Science Teaching, 33, 283-301.

Yenice, N., Sümer, Ş. Oktaylar, H.C. \& Erbil, E. (2003). Fen bilgisi derslerinde bilgisayar destekli öğretimin dersin hedeflerine ulaşma düzeyine etkisi. Hacettepe Üniversitesi Eğitim Fakültesi Dergisi 24, 152-158.

Yetişir, M. İ. (2014). The multilevel effects of student and classroom factors on the science achievement of eight graders in Turkey. Education and Science, 39(172), 108 120 .

Yiğit, N. \& Akdeniz, A. R. (2003). Fizik öğretiminde bilgisayar destekli etkinliklerin ögrenci kazanimlari üzerine etkisi: Elektrik devreleri örneği. Gazi Üniversitesi Eğitim Fakültesi Dergisi, 23(3), 99-113.

Yore, L. D., Anderson, J. O., \& Shymansky, J. A. (2002). Modeling the relationships of classroom characteristics and student attributes to students' science achievement. Annual Meeting of the National Association for Research in Science Teaching, (New Orleans, LA). 
Turkish Abstract

Fen Bilgisi Öğretmen Adaylarına Göre Öğrencilerin Fen Başarılarını Etkileyen Faktörlerin Araştırılması

Bu çalışmada fen bilgisi öğretmen adaylarına göre öğrencilerin fen başarılarını etkileyen faktörler incelenmektedir. Nicel araştırma yöntemlerinden taram modeli kullanılmıştır. Örneklem grubunu Türkiye'deki dört devlet üniversitesinde öğrenim gören toplam 606 öğrenci oluşturmaktadır. Veriler Öğrencilerin Fen Başarısını Etkileyen Faktörler Ölçeğiyle toplanmıştır Veriler betimsel analiz tekniği kullanılarak analiz edilmiştir. Öğrencilerin fen başarısını etkileyen faktörler 5 boyut altında analiz edilmiştir. Çalışmanın sonuçları fen bilgisi aday öğretmenlerine göre öğrencilerin fen başarılarını etkileyen en önemli faktörlerin öğretmen ve müfredat boyutlarındaki maddeler olduğunu göstemiştir. Sonuçlar ayrıca fen başarısının en önemli yordayıcısının ölçeğin öğretmen boyutundaki "konuları öğrencilerin merakını uyandıracak bir şekilde öğretme" olduğunu göstermiştir.

Anahtar Kelimeler: fen başarısının yordayıcıları, akademik başarı, fen eğitimi, öğretmen, öğrencileri etkileme

\section{French Abstract \\ Enquête de Facteurs Affectant l'Accomplissement de Science d'Étudiants Selon Professeurs de sciences d'Étudiant}

Dans cette étude, il a été visé à examiné les facteurs affectant l'accomplissement de science des étudiants selon des professeurs de sciences d'étudiant. Le modèle d'enquête qui est une des méthodes de recherche quantitatives a été utilisé. L'échantillon a été consisté en total 606 professeurs de sciences d'étudiant de quatre universités d'État en Turquie. Les données ont été obtenues en utilisant le Questionnaire de Facteurs Affectant l'Accomplissement de Science des Étudiants (QFASSA). Les données ont été analysées en utilisant la technique d'analyse descriptive. Les facteurs affectant l'accomplissement de science des étudiants ont été analysés sous cinq dimensions. Le résultat de l'étude montre que les facteurs les plus importants affectant l'accomplissement de science des étudiants selon des professeurs de sciences d'étudiant sont les articles dans les dimensions de professeur et le programme d'études. Les résultats indiquent aussi que le prophète le plus important d'accomplissement de science "enseigne les sujets dans une façon qui peut réveiller la curiosité des étudiants" dans la dimension de professeur de QFASSA.

Mots Clés: les prophètes d'accomplissement de science, accomplissement universitaire, enseignement des sciences, professeur, affectant étudiants

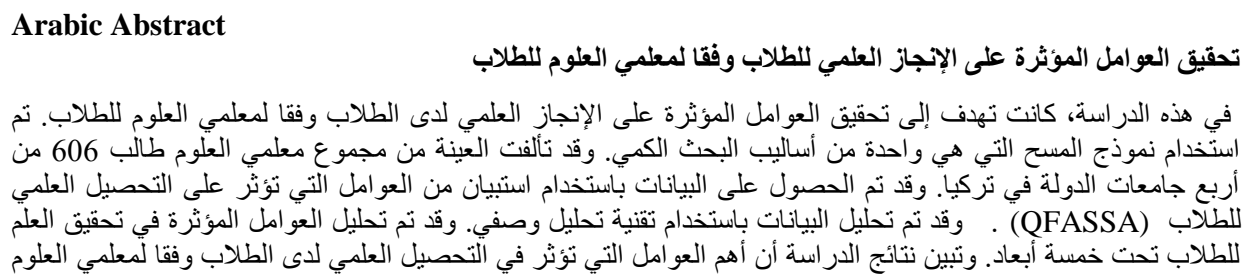

International Journal of Instruction, July $2016 \bullet$ Vol.9, No.2 


$$
\begin{aligned}
& \text { الطلابية هي العناصر في أبعاد المعلمين و المناهج الدراسية. كذلك تثشير النتائج إلى أن تنبؤ أهم من الإنجاز العلمي هو "تدريس }
\end{aligned}
$$

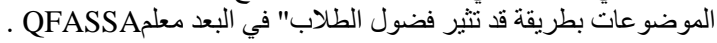

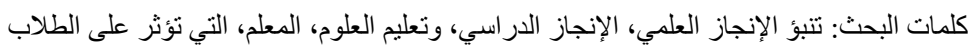

German Abstract

Untersuchung der Auswirkungen verschiedener Faktoren auf Wissenschaft Leistung der Studierenden nach Studien Lehrer für Wissenschaft

In dieser Studie wurde das Ziel, die Faktoren, die die Schüler Wissenschaft Leistung nach Student Wissenschaft Lehrer untersucht. Die Umfrage-Modell, das eine der quantitativen Forschungsmethoden ist, wurde verwendet. Die Probe wurde von insgesamt 606 Lehrer aus vier staatlichen Universitäten in der Türkei Student Wissenschaft bestand.. Die Daten wurden unter Verwendung von "den Fragebogen von Faktoren, die die Schüler Wissenschaft Leistung" erhalten. Die Daten wurden unter Verwendung der beschreibenden Analysetechnik analysiert. Die Faktoren, die die Wissenschaft Leistung beeinflussen Schüler wurden unter fünf Dimensionen analysiert. Das Ergebnis der Studie zeigt, dass die wichtigsten Faktoren der Schüler Wissenschaft Leistung beeinflussen gemäß Schüler Lehrer der Naturwissenschaften die Elemente in den Dimensionen der Lehrer und Lehrplan sind. Die Ergebnisse zeigen auch, dass der wichtigste Indikator für die Wissenschaft Errungenschaft ", die Themen in einer Art und Weise lehren, dass die Schüler die Neugier kann wecken" in der Lehrer Dimension der Fragebogen.

Schlüsselwörter: prädiktoren für wissenschaft leistung, akademische leistung, wissenschaft bildung, lehrer, schüler zu beeinflussen

\section{Malaysian Abstract \\ Penyiasatan Faktor Pencapaian Sains Pelajar Menurut Guru Sains}

Dalam kajian ini, ia bertujuan untuk mengkaji faktor-faktor yang mempengaruhi pencapaian sains pelajar mengikut guru sains pelajar. Model kajian yang merupakan salah satu kaedah penyelidikan kuantitatif telah digunakan. Sampel terdiri daripada jumlah 606 guru sains pelajar dari empat universiti kerajaan di Turki. Data yang telah diperolehi dengan menggunakan Soal Selidik Faktor Pencapaian Sains Pelajar (QFASSA). Data dianalisis dengan menggunakan teknik analisis deskriptif. Faktor-faktor yang mempengaruhi pencapaian sains pelajar telah dianalisis di bawah lima dimensi. Hasil kajian menunjukkan bahawa faktor yang paling penting yang mempengaruhi pencapaian sains pelajar mengikut guru sains pelajar adalah item dalam dimensi guru dan kurikulum. Keputusan juga menunjukkan bahawa peramal yang paling penting dengan pencapaian sains adalah "mengajar topik dengan cara yang boleh menimbulkan rasa ingin tahu pelajar" dalam dimensi guru daripada QFASSA.

Kata Kunci: peramal pencapaian sains, pencapaian akademik, pendidikan sains, guru, mempengaruhi pelajar 